\title{
Fra kardex til projektor
}

\author{
Innføring av projektor i rapportsituasjoner førte til bedre kvalitet på pleien og økt dokumentasjon.
}

$\mathbf{F}$ or to år siden begynte jeg å jobbe på sykehjem igjen, etter 20 år i sykepleierutdanningen. Min tidligere erfaring fra sykehjemmet var høy faglig standard, god pleie, gode rapporter og høy kontinuitet og kvalitet. Da jeg kom tilbake opplevde noe jeg anså som et stort tilbakeskritt når det gjaldt dokumentasjon. Mitt inntrykk var at de ansatte ikke hadde funnet ut hvordan de skulle implementere dataverktøyet i sin hverdag, og gjøre det til et allemannseie i avdelinga.

\section{Mangelfull rapportering}

Datamaskinene sto på avdelinga og rapportene ble skrevet inn. Det var stort sett sykepleiere som skrev, og som oftest bare når det var store forandringer hos pasientene. Det kunne gå uker mellom hver nedtegnelse som ble gjort av enkelte ansatte. Det var mange

\section{Hovedbudskap}

Artikkelen handler om å bruke projektor i rapportsituasjon i sykehjemsavdeling. Dette virket samlende, $ø k$ te dokumentasjonsfrekvensen og førte til en bedre kontinuitet i pleien på vår avdeling.

\section{Nøkkelord}

Les mer og finn litteraturhenvisninger på våre nettsider. ) Dokumentasjon /Informasjonsteknologi | Informasjon | Sykehjem / Fagutviklingsprosjekt ulike forklaringer. Begrunnelse kunne være at «jeg har ikke passord», «jeg vet ikke hva jeg skal skrive», «jeg vet ikke hvordan jeg skal skrive dette», «dette kan vi ikke skrive» og så videre. Så da var det bedre å la være. I rapportsituasjonene satt man med «dolista» (liste over alle pasientenes avføringsvaner) for å ha en huskeliste slik at alle navnene skulle bli nevnt, men ellers var rapporten basert på en muntlig overføring av det som var relevant, og lite av det som ble sagt ble skrevet ned. Personalet noterte ned på egne blokker.

\section{Rapport på lerret}

Tilfeldighetene førte meg til et møte på politistasjonen, der de fortalte om hvordan de hadde endret sine rapportsituasjoner for å bedre informasjonsflyten. De hadde begynt å bruke projektor og lerret for å dele informasjonen i rapporter og fellesmøter. Tilbake på sykehjemmet hengte vi opp et laken i taklista på vaktrommet, og koplet opp en bærbar projektor til datamaskinen. Så gikk vi gjennom rapporten på lerretet. «Dette var bra!»var den umiddelbare reaksjonen fra de ansatte. Man kunne lese på skjermen i fellesskap og ble oppmerksomme på hvor mangelfullt det var og hvor lite som sto der. Deretter kunne vi i fellesskap gjennomgå hva som burde stå der. Vi underviste hverandre i å skrive inn informasjonen, hvor den skulle plasseres og hvordan vi kunne bygge den opp. Terskelen for å prøve og spørre sank fort. Det ble mange gode diskusjoner.

\section{Redusert datafrykt}

Ledelsen støttet ideen, vi fikk fastmontert projektor i taket på vaktrommet og senkbart lerret på veggen. Frykten for å logge seg inn på data ble overraskende fort redusert. Alle fikk pålegg om å skaffe seg passord og måtte lære å logge seg inn. Vi hadde fagdag for hele avdelinga der vi fokuserte på dokumentasjon, og jobbet med oppbygging og systematisering av dokumentasjon på data. Det ble etter hvert stor iver blant personalet. Og med støtte og hjelp, mildt press og oppmuntring, kom alle etter hvert i gang med å dokumentere eget

\section{«Det kunne gå uker mellom hver ned- tegnelse.»}

arbeid. Vi diskuterte mye rundt viktigheten av dette, og at det faktisk ikke er lov til å dokumentere for andre eller låne en id. $\mathrm{Pa}$ sientrettighetsloven og helsepersonelloven stiller klare krav til dette $(1,2)$.

\section{Bedre oversikt}

Etter hvert steg motivasjonen. Personalet kunne følge med på rapporten som ble gitt, og lese den selv samtidig. Ble ikke alt nevnt, fanget de likevel opp mye. For deltidsansatte ble det enklere å følge med på hva som hadde skjedd etter friperioder, fordi rapporten fra flere dager tilbake også sto på skjermen. Det 


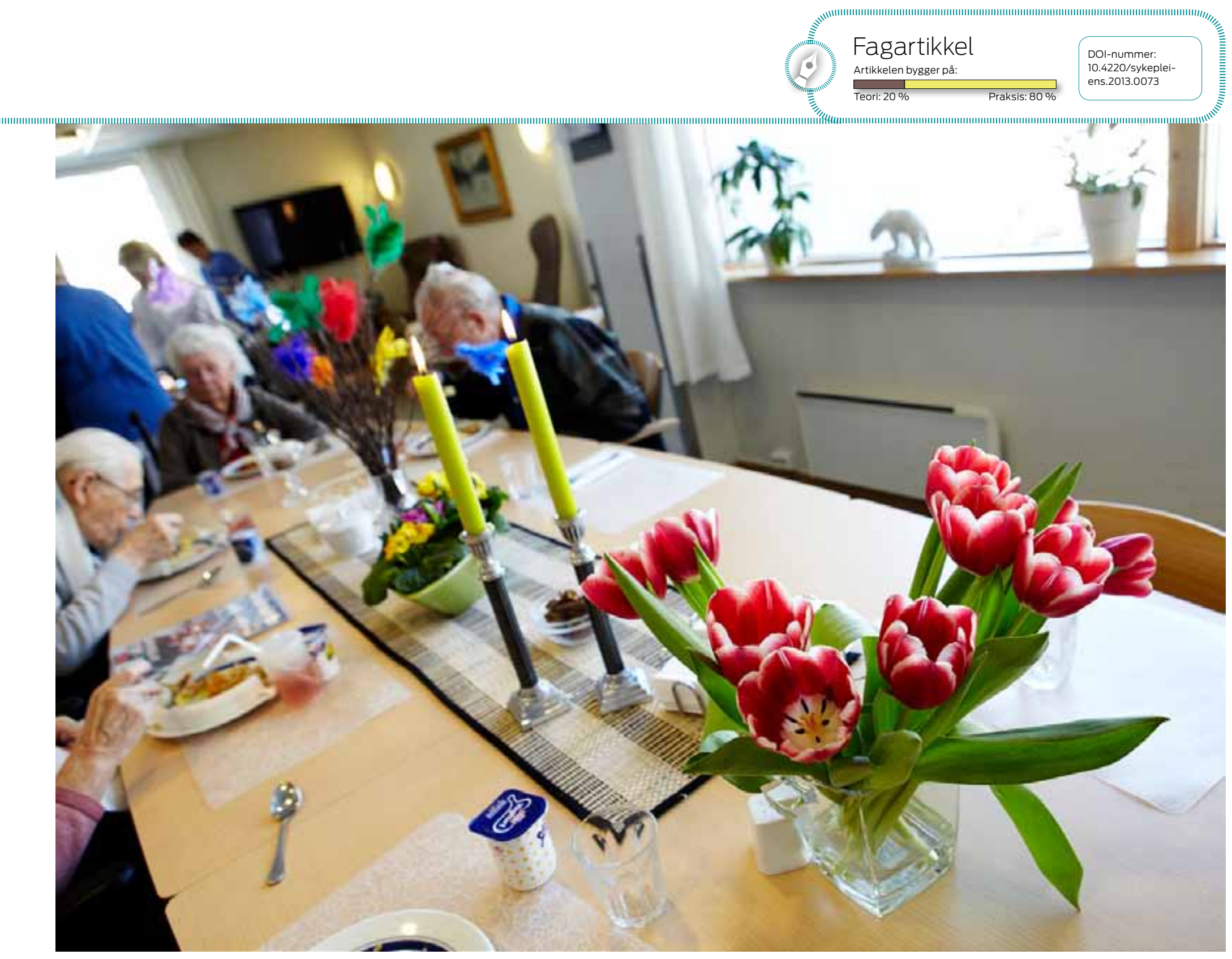

BEDRE PLEIE: Kontinuiteten i pleien økte ved sykehjemmet etter at de ansatte gjennomgikk rapporten med projektor. Arkivfoto: Erik M. Sundt

ble enklere å holde oversikten, og kontinuiteten i pleien ble bedre. Uttaleleser fra personalet som: «Dette er kjempebra”, «Nå føler jeg at jeg får oversikten selv om jeg har hatt fri noen dager», «Det beste som har skjedd oss siden kardexen forsvant» sier jo sitt. Motivasjon utvikles gjennom å reflektere over egne behov og ønsker for læring (3).

Forskning viser at også hukommelsen blir påvirket av å få inntrykk gjennom flere sanser. Når man både hører og i tillegg ser det som blir sagt i rapporten, aktiveres både korttidshukommelse og langtidshukommelse, og informasjonen lagres bedre i hjernen. Det har vist seg at mennesket lærer generelt bedre av bilder enn av ord, både ved gjenkjenning og gjenkalling av informasjon (4).

\section{$\varnothing$ Øt dokumentasjon}

Projektor og datamaskin har blitt en sentral del av vår hverdag, og vi utnytter den også i andre sammenhenger. I internundervisning for eksempel, er det lett å slå opp en prose- dyre, en videosnutt fra nettet eller en dvd som kan instruere eller gi grunnlag for diskusjon. Skjermen virker samlende og engasjerer, og gir et godt utgangspunkt for felles refleksjon over egen praksis. Vi er fremdeles bare i startgropa, og kommer til å utnytte dette mer og mer ettersom vi blir mer fortrolig med mediet. Vi har også kjøpt ekstern høyttaler for å bedre lyden.

Som avdelingsleder ser jeg hvordan fag og dokumentasjon atter er blitt sentralt i arbeidsdagen. Kjeden i sykepleieprosessen med datasamling, tiltak, vurdering og evaluering er igjen blitt komplett, arbeidet er blitt mer kunnskapsbasert (5). Vi har fått en merkbar heving av kvaliteten i pleien, og datavegringen blir sjelden nevnt. En kort stikkprøve av rapporteringsmengde viser at avdelinga for et år siden hadde cirka 11 sider dokumentasjon på en måned, i dag har vi 81 sider. Dette har jo ikke bare en entydig årsak, men viser i hvert fall en stor økning.

\section{Avslutning}

Avdelinga vår er stor, det er mellom 40 og 50 ansatte med alle deltidsbrøker, og gjennomsnittsalderen er rundt 48 år. Erfaring med data var svært varierende hos hver enkelt ansatt, mange har beveget seg inn i en verden de før ikke var så komfortable med. Men jeg er virkelig stolt av hvordan personalet har taklet dette, og ser optimistisk på framtida. Erfaringene med bruk av projektor var så gode, at Rana kommune besluttet å kjøpe inn lerret og projektor til alle sine avdelinger i sykehjem og hjemmetjenesten. IIII

\section{REFERANSER}

1. http://www.lovdata.no/all/nl-19990702-063.html (24.11.12)

2. http://wwwlovdata no/all/nt-19990702-064.html (2411.12)

Steinsholt K. " Paulo Freire: Håpets pedagogikk" i Steinsholt og Løvlie, Pedagogikkens mange ansikter. Oslo: Universitetsforlaget, 2004.

Torgersen GE. Læring med IT, Teori og metode for undervisning med informasjon og kommunikasjonsteknologi. Oslo: Næringslivets Forlag, 1998.

5. Nortvedt MW, m.fl. A arbeide og undervise kunnskapsbasert - en arbeidsbok for sykepleiere. Oslo: Norsk Sykepleierforbund, 2007.

Fagartikler kan sendes til torhild.apall@sykepleien.no 